\title{
Performance Specification for Standardized Transportation, Aging, and Disposal Canister Systems
}

Fuel Cycle Research \& Development

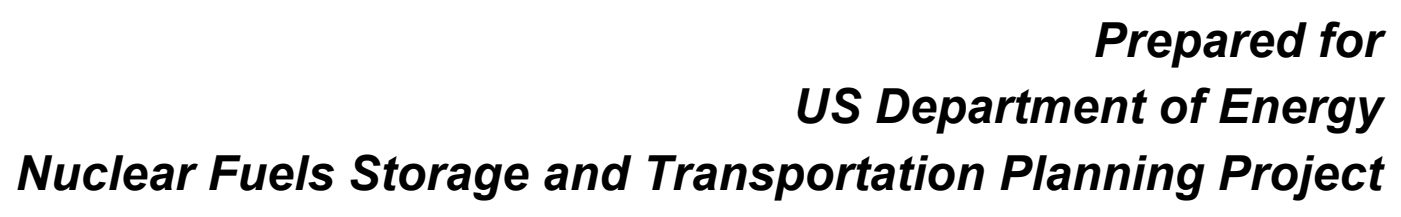

Prepared by Oak Ridge National Laboratory

July 20, 2015

FCRD- NFST-2014-000579, Rev. 2

ORNL/SPR-2015/251 


\section{DISCLAIMER}

This information was prepared as an account of work sponsored by an agency of the U.S. Government. Neither the U.S. Government nor any agency thereof, nor any of their employees, makes any warranty, expressed or implied, or assumes any legal liability or responsibility for the accuracy, completeness, or usefulness, of any information, apparatus, product, or process disclosed, or represents that its use would not infringe privately owned rights. References herein to any specific commercial product, process, or service by trade name, trade mark, manufacturer, or otherwise, does not necessarily constitute or imply its endorsement, recommendation, or favoring by the U.S. Government or any agency thereof. The views and opinions of authors expressed herein do not necessarily state or reflect those of the U.S. Government or any agency thereof. 
Name/Title of

Deliverable/Milestone/Revision No.

Work Package Title and Number

Work Package WBS Number

Responsible Work Package Manager

\section{Appendix E}

FCT Document Cover Sheet

Performance Specification for Standardized Transportation, Aging, and Disposal Canister Systems, FCRD-NFST-2014000579, M2FT-15OR0904022, Rev. 2

Standardization and Integration, ORNL-FT-15OR090402

1.02 .09 .04

Rob Howard/

(Name/Signature)

Date Submitted June 30, 2015

\begin{tabular}{|c|c|c|c|c|}
\hline $\begin{array}{l}\text { Quality Rigor Level for } \\
\text { Deliverable/Milestone }\end{array}$ & $\square$ QRL-3 & $\square$ QRL-2 & $\begin{array}{l}\bigotimes \text { QRL-1 } \\
\square \text { Nuclear Data }\end{array}$ & $\begin{array}{l}\square \text { Lab Participant } \\
\text { QA Program (No } \\
\text { additional FCT QA } \\
\text { requirements) }\end{array}$ \\
\hline \multicolumn{5}{|c|}{ This deliverable was prepared in accordance with } \\
\hline
\end{tabular}

QA program which meets the requirements of
$\square$ DOE Order 414.1
$\square$ NQA-1-2000
\ NQA-1-2008

This Deliverable was subjected to:

$\bigotimes$ Technical Review

Technical Review (TR)

Review Documentation Provided

$\square$ Signed TR Report or,

$\square$ Signed TR Concurrence Sheet or,

$\bigotimes$ Signature of TR Reviewer(s) below

Name and Signature of Reyiewers

Mark C. Vance/ $7 / 23 / 15$

Kaushik Banerjee and Georgeta Radulescu/(See attached ORNL Publication Tracking System form on the next page.)

NOTE 1: Appendix E should be filled out and submitted with the deliverable. Or, if the PICS:NE system permits, completely enter all applicable information in the PICS:NE Deliverable Form. The requirement is to ensure that all applicable information is entered either in the PICS:NE system or by using the FCT Document Cover Sheet.

NOTE 2: In some cases there may be a milestone where an item is being fabricated, maintenance is being performed on a facility, or a document is being issued through a formal document control process where it specifically calls out a formal review of the document. In these cases, documentation (e.g., inspection report, maintenance request, work planning package documentation or the documented review of the issued document through the document control process) of the completion of the activity, along with the Document Cover Sheet, is sufficient to demonstrate achieving the milestone. If QRL 1, 2, or 3 is not assigned, then the Lab / Participant QA Program (no additional FCT QA requirements) box must be checked, and the work is understood to be performed and any deliverable developed in conformance with the respective National Laboratory/Participant, DOE or NNSA-approved QA Program. 
Performance Specification for Standardized Transportation, Aging, and Disposal Canister Systems, FCRD-NFST-2014-000579, Rev. 2

\begin{tabular}{|c|c|c|c|c|}
\hline Pub ID & \multicolumn{4}{|l|}{55888} \\
\hline Title & \multicolumn{4}{|c|}{ Performance Specification for Standardized Transportation, Aging, and Disposal Canister Systems R2 } \\
\hline Status & \multicolumn{4}{|l|}{ Submitted for review } \\
\hline Communication Type & \multicolumn{4}{|l|}{ ORNL report } \\
\hline ORNL Review? & \multicolumn{4}{|c|}{ Scientific communication that requires ORNL review } \\
\hline Information Category & \multicolumn{4}{|l|}{ Unlimited } \\
\hline Contact Person & \multicolumn{4}{|l|}{ Beatty, Andrea L } \\
\hline Responsible Organization & \multicolumn{4}{|c|}{ Reactor \& Nuclear Systems Division (50159781) } \\
\hline Prepared at & \multicolumn{4}{|c|}{ This scientific communication is being prepared by someone at ORNL. } \\
\hline Internal Access & \multicolumn{4}{|c|}{ Available to this document's authors and reviewers / approvers and line management. } \\
\hline Authors & $\begin{array}{l}\text { Blink, James } \\
\text { Alsaed, Abdelhalim } \\
\text { Nutt, Mark } \\
\text { Gutherman, Brian } \\
\text { Bevard, Bruce Balkcom } \\
\text { Howard, Rob L. } \\
\text { Jarrell, Joshua J. } \\
\text { Scaglione, John M. } \\
\text { Wagner, John C. } \\
\text { Maheras, S J } \\
\text { Bryan, C.L. } \\
\text { Hardin, Ernest } \\
\text { Ilgen, Anastasia } \\
\text { Kalinina, Elena }\end{array}$ & \multicolumn{3}{|c|}{$\begin{array}{l}\text { Beckman and Associates, Inc. } \\
\text { Enviro Nuclear Services, LLC } \\
\text { Argonne National Laboratory (ANL) } \\
\text { Gutherman Technical Services, LLC } \\
\text { ORNL ( } 34137) \\
\text { ORNL ( } 977937) \\
\text { ORNL (975711) } \\
\text { ORNL (939679) } \\
\text { ORNL (37727) } \\
\text { Pacific Northwest National Laboratory (PNNL) } \\
\text { Sandia National Laboratories (SNL) } \\
\text { Sandia National Laboratories (SNL) } \\
\text { Sandia National Laboratories (SNL) } \\
\text { Sandia National Laboratories (SNL) }\end{array}$} \\
\hline \multicolumn{5}{|l|}{ Acknowledgements } \\
\hline Workflow & $\begin{array}{l}05 / 19 / 201511: 48: 34 \\
05 / 19 / 201513: 16: 40 \\
05 / 19 / 201513: 16: 40 \\
05 / 19 / 201513: 22: 15 \\
05 / 19 / 201514: 39: 40 \\
05 / 20 / 201509: 29: 20 \\
05 / 20 / 201513: 06: 44 \\
05 / 22 / 201516: 31: 21 \\
05 / 27 / 201514: 24: 51 \\
06 / 15 / 201511: 18: 18 \\
07 / 20 / 201509: 45: 02 \\
07 / 20 / 201516: 24: 52 \\
07 / 20 / 201517: 55: 01 \\
07 / 21 / 201508: 44: 00 \\
07 / 21 / 201516: 28: 24 \\
07 / 22 / 201512: 07: 34 \\
07 / 22 / 201512: 07: 45 \\
07 / 22 / 201516: 56: 46\end{array}$ & $\begin{array}{l}\text { Draft } \\
\text { Author Certification } \\
\text { Submitted for review } \\
\text { Supervisor } \\
\text { Derivative Classifier } \\
\text { Technical Reviewer } \\
\text { Technical Reviewer } \\
\text { Changed communication type } \\
\text { Technical Editor } \\
\text { Changed communication type } \\
\text { Administrative Check } \\
\text { Supervisor } \\
\text { Program Manager } \\
\text { Information Classification } \\
\text { Division Approver } \\
\text { Changed communication type } \\
\text { Changed communication type } \\
\text { Changed communication type } \\
\text { Waitina on the following review }\end{array}$ & $\begin{array}{l}\text { Beatty, Andrea L } \\
\text { Bevard, Bruce Balkcom } \\
\text { Bevard, Bruce Balkcom } \\
\text { Scaglione, John M } \\
\text { Poe, Christopher D by Kyle, John S } \\
\text { Banerjee, Kaushik } \\
\text { Radulescu, Georgeta } \\
\text { Gawne, Timothy J } \\
\text { Koncinski, Walter S } \\
\text { Gawne, Timothy J } \\
\text { Beatty, Andrea L } \\
\text { Scaglione, John M } \\
\text { Howard, Rob L } \\
\text { Poe, Christopher D by Kyle, John S } \\
\text { Wagner, John C } \\
\text { Beatty, Andrea L } \\
\text { Beatty, Andrea L } \\
\text { Gawne, Timothy J }\end{array}$ & $\begin{array}{l}\text { Approved } \\
\text { Cleared } \\
\text { Recommended } \\
\text { Recommended } \\
\text { Recommended } \\
\text { Recommended } \\
\text { Approved } \\
\text { Approved } \\
\text { Cleared } \\
\text { Approved }\end{array}$ \\
\hline
\end{tabular}




\section{ACKNOWLEDGMENTS}

Technical contributors to Revisions 0,1 , and 2 of this report include all those listed below:

Argonne National Laboratory:

Mark Nutt

Beckman \& Associates, Inc. James A. Blink

Enviro Nuclear Services, LLC Abdelhalim Alsaed

Gutherman Technical Services, LLC Brian Gutherman
Oak Ridge National Laboratory:

Kaushik Banerjee

Bruce B. Bevard

Matthew R. Feldman

Rob L. Howard

Josh Jarrell

Georgeta Radulescu

John M. Scaglione

Mark C. Vance

John C. Wagner

Pacific Northwest National Laboratory

Steve Maheras

Sandia National Laboratories:

Charles Bryan

Ernest Hardin

Anastasia Ilgen

Elena Kalinina 
Performance Specification for Standardized Transportation, Aging, and Disposal Canister Systems,

\section{PAGE INTENTIONALLY LEFT BLANK}




\section{REVISION HISTORY}

July 27, 2014: Rev. 0, Initial Issue. Title: "Performance Specification for Small and Medium Standardized Transportable, Aging, and Disposal Canister Systems".

April 30, 2015: Rev. 1. Title changed to "Performance Specification for Standardized Transportable, Aging, and Disposal Canister Systems" to reflect the addition of the large 21-PWR/44-BWR spent nuclear fuel assembly standardized transportation, aging, and disposal (STAD) specification. Other changes reflect adoption of accepted methods in the pertinent NUREG Standard Review Plans whenever feasible, and clarification of requirements beyond the Code of Federal Regulation (CFR) requirements and NUREG Standard Review Plan guidance. Due to the extensive changes, no change bars are included in the document.

July 20, 2015: Rev. 2. Corrects minor errors. Clarifies the versions of ASME-NQA-1. Clarifies that this document does not require STAD canisters to accept damaged fuel although that requirement may be added in a future revision. Clarifies the requirement to design canister internals to meet potential disposal thermal considerations. Revisions are indicated by bars in the margins. 
Performance Specification for Standardized Transportation, Aging, and Disposal Canister Systems,

PAGE INTENTIONALLY

LEFT BLANK 


\section{EXECUTIVE SUMMARY}

This performance specification document addresses use of a standardized transportation, aging, and disposal (STAD) canister system in the spent nuclear fuel (SNF) waste management system. This document was developed to support STAD canister system studies and potential research, development, and demonstration activities. Requirements in this specification may evolve with time based on results from analyses, experiments, design studies, system evaluations and demonstrations, as well as other factors.

A STAD canister system consists of a canister, together with a storage or aging overpack/module/vault, a shielded transfer cask (STC), a site transporter, a transportation overpack, and a transportation skid. Three sizes of circular cross section STAD canister variants are specified in this document. The small STAD canister capacity is four pressurized water reactor (PWR) or nine boiling water reactor (BWR) SNF assemblies. The medium STAD canister capacity is 12 PWR or 32 BWR SNF assemblies. The large STAD canister capacity is 21 PWR or 44 BWR SNF assemblies. Using standardized canisters for SNF facilitates the interface between storage at an independent spent fuel storage installation (ISFSI) or a DOEowned interim storage facility (ISF), transportation between facilities, and disposal at a repository. Multiple STAD canisters may be stored in a single storage overpack and/or a single transportation overpack.

The US Nuclear Regulatory Commission (NRC) requirements currently used for storage and transportation are adopted for the STAD canister system. Approved approaches (guidance) in NRC storage and transportation documents are also adopted as requirements for the STAD canister system to facilitate obtaining NRC Certificates of Compliance (CoCs) for STAD canister systems. Performance specifications in this document are also informed by STAD canister disposability in various geologic media and consideration of ISF (and geologic repository) handling facility design, operations, and licensing requirements. 
Performance Specification for Standardized Transportation, Aging, and Disposal Canister Systems, FCRD-NFST-2014-000579, Rev. 2 July 20, 2015

\section{PAGE INTENTIONALLY LEFT BLANK}


Performance Specification for Standardized Transportation, Aging, and Disposal Canister Systems, FCRD-NFST-2014-000579, Rev. 2

July 20, 2015

\section{CONTENTS}

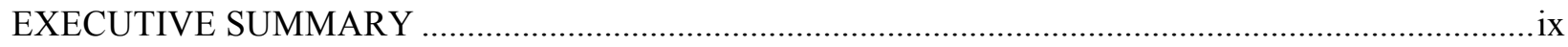

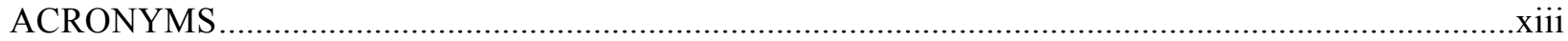

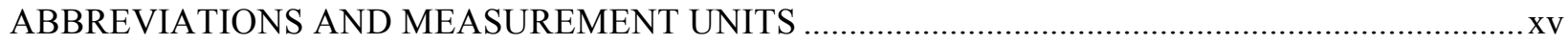

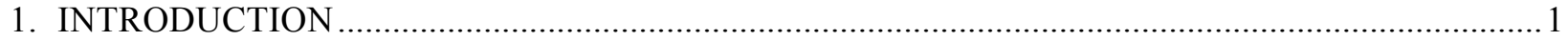

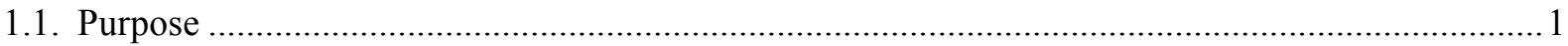

1.2. Standardized Transportation, Aging, and Disposal System Description........................................

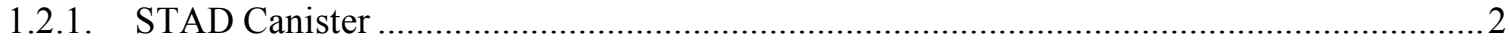

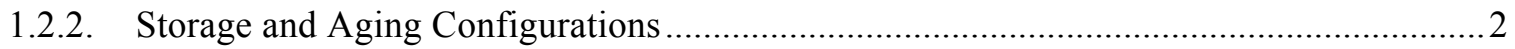

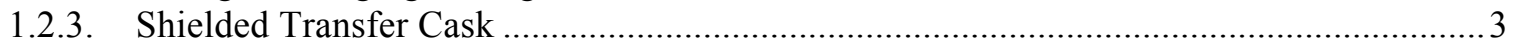

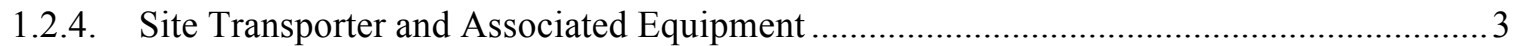

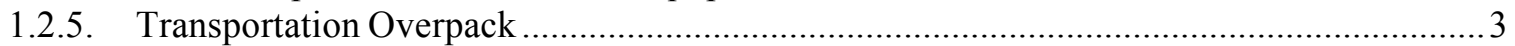

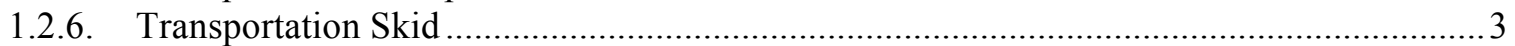

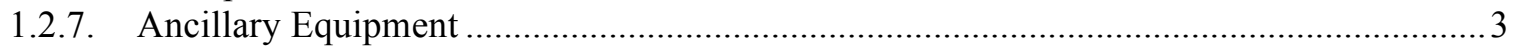

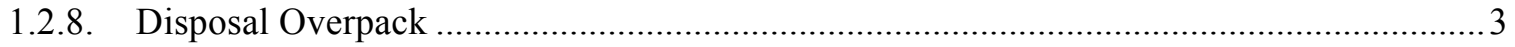

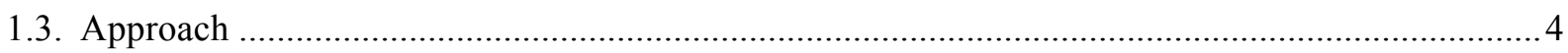

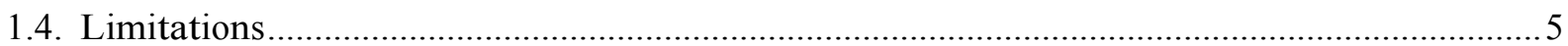

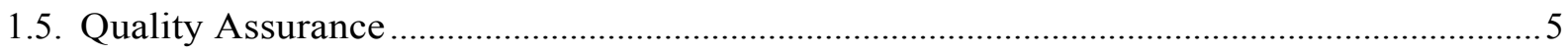

2. REQUIREMENTS AND GUIDANCE DOCUMENTS, CODES AND STANDARDS .......................7

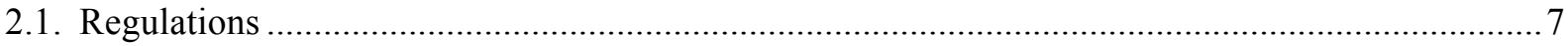

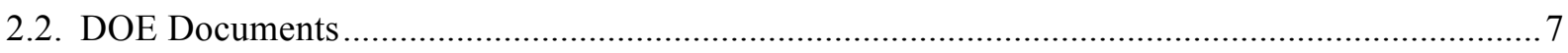

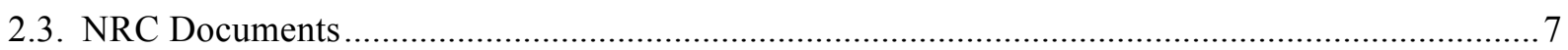

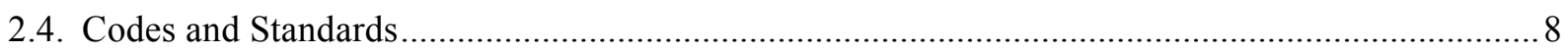

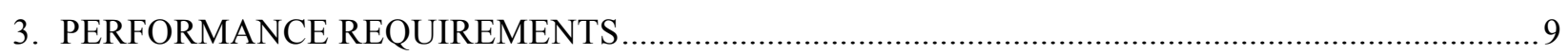

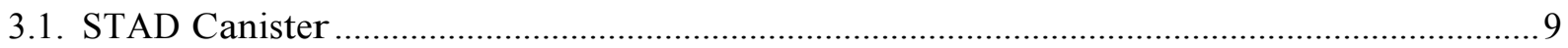

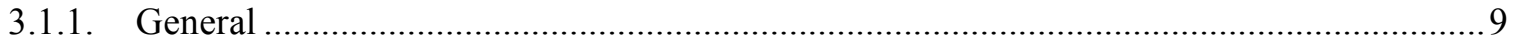

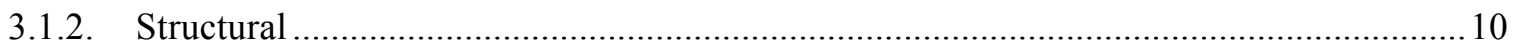

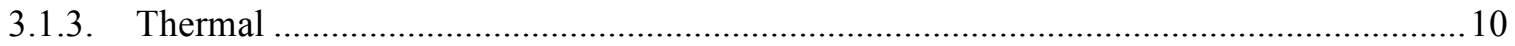

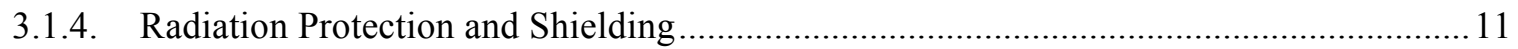

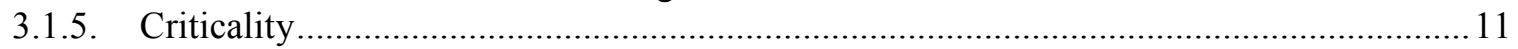

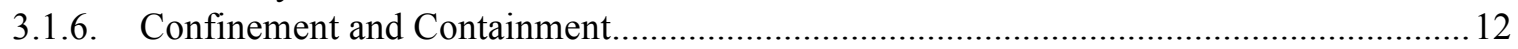

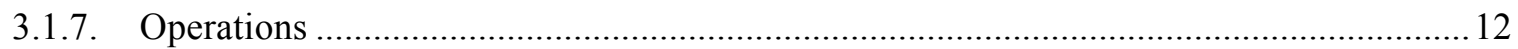

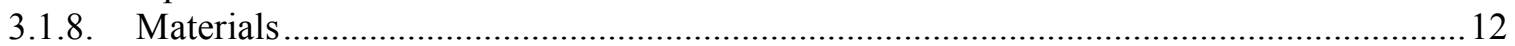

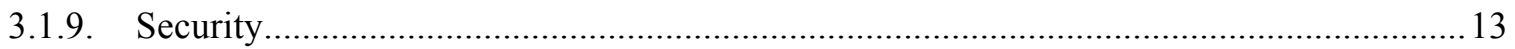

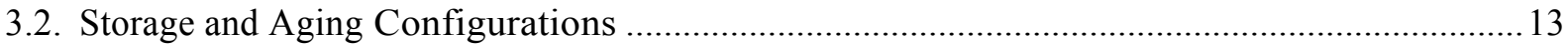

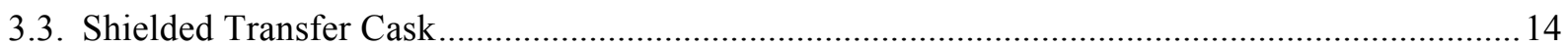

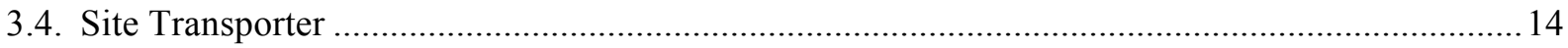

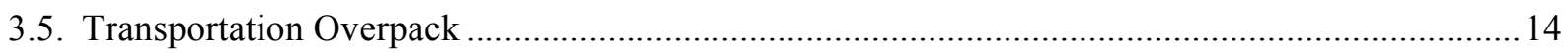

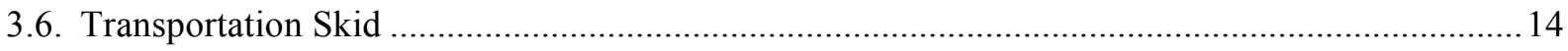

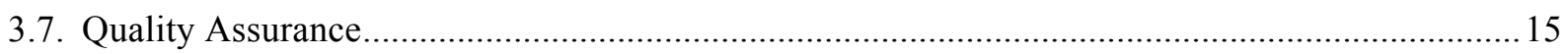

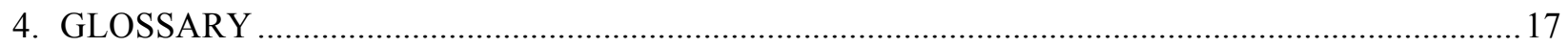

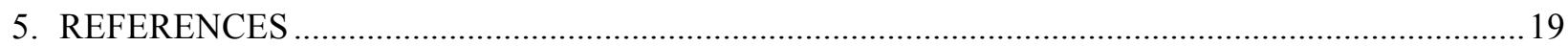


Performance Specification for Standardized Transportation, Aging, and Disposal Canister Systems, FCRD-NFST-2014-000579, Rev. 2

xii July 20, 2015

TABLES

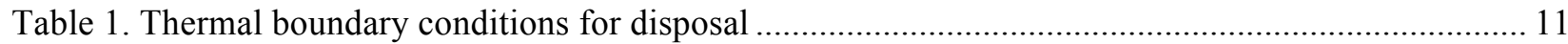




\section{ACRONYMS}

AAR Association of American Railroads

AASHTO American Association of State Highway and Transportation Officials

ALARA as low as reasonably achievable

ANS American Nuclear Society

ANSI American National Standards Institute

ASME American Society of Mechanical Engineers

ASTM American Society for Testing and Materials

BWR boiling water reactor

CoC NRC Certificate of Compliance

CFR Code of Federal Regulations

DE design earthquake

DOE US Department of Energy

EPA Environmental Protection Agency

FCRD Fuel Cycle Research and Development

GI generic issue (NRC)

GTCC greater than class C

HAC hypothetical accident condition

HLW high-level radioactive waste

IEEE Institute of Electrical and Electronics Engineers

ISF Interim Storage Facility (for the purposes of this document, an ISF can be a DOE-owned MRS or a privately owned ISFSI not co-located with a nuclear power plant)

ISFSI independent spent fuel storage installation

ISG interim staff guidance

ISO International Organization for Standardization

MPC multipurpose canister

MRS monitored retrievable storage installation (DOE-owned) per the Nuclear Waste Policy Act and 10 CFR Part 72

NCT normal conditions of transport

NFST Nuclear Fuels Storage and Transportation

NPP nuclear power plant

NQA Nuclear Quality Assurance

NRC US Nuclear Regulatory Commission

PWR pressurized water reactor

RCRA Resource Conservation and Recovery Act

RIS regulatory issue summary (NRC)

SFST spent fuel storage and transportation

SKB Swedish Nuclear Fuel and Waste Management Company

SNF spent nuclear fuel

STAD standardized transportation, aging, and disposal

STC shielded transfer cask

TAD transportation, aging, and disposal 
Performance Specification for Standardized Transportation, Aging, and Disposal Canister Systems, FCRD-NFST-2014-000579, Rev. 2

xiv July 20, 2015

TPBAR tritium-producing burnable absorber rods

UFD Used Fuel Disposition

UNS unified numbering system (for metal alloys) 
Performance Specification for Standardized Transportation, Aging, and Disposal Canister Systems, FCRD-NFST-2014-000579, Rev. 2

\section{ABBREVIATIONS AND MEASUREMENT UNITS}

${ }^{\circ} \mathrm{C}$

degrees Centigrade

Amd amendment (to an ISO standard)

$\mathrm{cm}^{2} \quad$ square centimeter

Cor corrigendum (to an ISO standard)

dpm disintegrations per minute

GWd gigawatt-day

in. inch

kg kilogram

m meter

MTU metric tons of uranium

Rev Revision

W watt

wt $\% \quad$ weight percent 
Performance Specification for Standardized Transportation, Aging, and Disposal Canister Systems, FCRD-NFST-2014-000579, Rev. 2

$\mathrm{xvi}$ July 20,2015

\section{PAGE INTENTIONALLY LEFT BLANK}




\section{PERFORMANCE SPECIFICATION FOR STANDARDIZED TRANSPORTATION, AGING, AND DISPOSAL CANISTER SYSTEMS}

\section{INTRODUCTION}

Nuclear utilities make site-specific determinations on how to manage their spent nuclear fuel (SNF). For dry storage, utilities use high-capacity canisters and casks that are able to hold up to 40 pressurized water reactor (PWR) assemblies or up to 89 boiling water reactor (BWR) assemblies. Key factors in determining canister or cask design include worker dose, operational impacts of fuel loading, and cost.

The concept of a canister system capable of storage, transportation, and disposal without repackaging has been developed and discussed for many years. Past work considered the multipurpose canister (MPC) system and the transportation, aging, and disposal (TAD) canister system that was developed to be compatible with a repository in volcanic tuff (Hardin et al. 2012, Hardin et al. 2013). The potential benefits of this type of system include the following:

- Reduced overall waste management system cost

- Increased flexibility and/or reduced sensitivity to future decisions and to changes in waste management strategies

- Streamlined handling, packaging, and licensing at an interim storage facility (ISF) and/or repository

- Streamlined transportation hardware and operations

- Reduced uncertainties associated with waste acceptance and system performance

- Minimized amount of repackaging

- Reduced handling of individual fuel assemblies leading to reduced probability of assembly mishandling or drops, as well as reduced concerns related to fuel condition following extended storage and transportation. This may facilitate defining retrieval at the canister level as opposed to the assembly level.

\subsection{Purpose}

This document provides specifications for selected system components of a standardized transportation, aging, and disposal (STAD) canister-based system. This document was developed to support STAD canister system studies and potential research, development, and demonstration activities. Requirements in this specification may evolve with time based on results from analyses, experiments, design studies, system evaluations and demonstrations, as well as other factors.

The STAD canister, in conjunction with specialized storage and transportation overpacks, storage and aging facilities, and ancillary equipment, would accomplish multiple functions in the management of SNF. Some of these functions would be accomplished by owners or generators at their sites where SNF is stored, and some would be performed by DOE after acceptance of the SNF within a federal-government-managed transportation, interim storage, and disposal system. This document contains only those requirements unique to applications within a federal SNF management system. Requirements to meet utility functions such as onsite dry storage, handling, and loading for transportation are determined by the utility licensing process and are expected to be similar to commercially available canister-based systems. 
This document contains performance specifications for the STAD canister, the storage or aging overpack/module/vault, the shielded transfer cask (STC), the site transporter, the transportation overpack, and the transportation skid. Other components (e.g., disposal overpack) and equipment unique to a federal repository will be developed in the future.

Other than interfacing with the STAD canisters and other STAD system components, the design of an independent spent fuel storage installation (ISFSI) or a federal ISF is beyond the scope of this performance specification document.

\subsection{Standardized Transportation, Aging, and Disposal System Description}

A STAD system consists of one or more canister(s), storage or aging overpack/module/vault, shielded transfer cask, site transporter, transportation overpack, and transportation skid. Because the disposal environment is currently unknown, no disposal overpack can be specifically defined at this time. However, it is expected that the canister would eventually be placed in a disposal overpack for disposal. The disposal overpack with its contents is referred to as a waste package.

\subsubsection{STAD Canister}

A STAD canister would be loaded with commercial SNF and sealed at an existing 10 Code of Federal Regulations (CFR) Part 50 facility, existing or future ISFSI or ISF, or future geologic repository surface facility. The loaded STAD canister could be used for storage for a period of time at ISFSI facilities or a federal ISF, and it could be transported between facilities. Therefore, the STAD canister storage and transportation system designer would have to obtain NRC Certificates of Compliance (CoCs) in accordance with 10 CFR Parts 72 and 71, respectively. For example, the STAD canister system might be stored at an ISFSI, followed by transportation, followed by storage at an ISF, followed by transportation, and followed by aging at a repository). At an ISF, a loaded STAD canister might also be handled using an STC and stored in a storage overpack/module/vault. At a geologic repository, a loaded STAD canister might also be handled using an STC and aged in an aging overpack/module/vault. Ultimately, loaded STAD canisters would be placed in disposal overpacks for disposal. Although regulatory requirements associated with disposal of STAD canisters are outside the scope of this performance specification document, some STAD canister performance specifications are informed by disposal considerations.

The capacity (PWR or BWR assemblies) of a STAD canister is a key performance parameter. Currently, storage and transportation designs aim at maximizing the number of assemblies in a single canister. At a repository, the waste package capacity could be small, ranging from 4 PWR assemblies in some geologic media up to 21 PWR assemblies in a repository license application (DOE, 2008a). Because of these contrasting capacities, the STAD canister may be modular. That is, one or more STAD canisters may be loaded into a single storage overpack or transportation overpack. At this time, STAD modularity is limited to circular cross section STAD canisters. The key advantage of a modular STAD canister is that once SNF assemblies are packaged into a STAD canister, they would not require repackaging as they move through the sequential facilities that comprise the waste management system.

\subsubsection{Storage and Aging Configurations}

Storage and aging are related phases in the lifecycle of SNF. Storage may be done for operational reasons including utility SNF pool capacity limitations and consolidation of SNF pending the availability of a downstream facility. Aging is storage for the purpose of reducing the thermal load, such that the SNF can be transported or disposed. Storage and aging configurations for STAD canisters include the potential use of storage/aging overpacks, modules, or vault systems. Overpacks/modules/vaults may be designed to contain single or multiple STAD canisters and would be used to safely contain loaded STAD canisters at a 
storage or aging facility (ISFSI, ISF, repository surface facility) until transported or emplaced in a repository. The storage or aging overpack/module/vault, in conjunction with the STAD canister, would ensure compliance with storage safety functional requirements including confinement, radiological protection, criticality safety, retrievability, and thermal performance during normal operations, off-normal conditions, and design basis accidents. Storage overpacks must be designed to meet the requirements of 10 CFR Part 72.

\subsubsection{Shielded Transfer Cask}

The STC would be used for intrasite transfer of a loaded STAD canister or group of canisters at an ISFSI, ISF, or repository surface facility. The STC would facilitate loading into a storage/aging overpack/module/vault, transportation overpack, or repository disposal overpack. It would protect the STAD canister from damage, protect workers from radiation, and allow for required heat dissipation. The STC must be designed to meet the requirements of 10 CFR Part 72.

\subsubsection{Site Transporter and Associated Equipment}

The site transporter is a vehicle that would be used for transporting loaded and unloaded STCs at an ISFSI, ISF, or repository aging facility. The transporter would provide support for STCs during loading and unloading operations. The site transporter might also be capable of moving the loaded transportation overpack (with or without the transportation skid). Alternatively, the applicant for an NRC license or CoC could design separate transporters for the STC and transportation overpack.

\subsubsection{Transportation Overpack}

The transportation overpack is an overpack that would be certified in accordance with 10 CFR Part 71 as a packaging component used to enclose one or more STAD canisters for transportation. The transportation overpack, in conjunction with the STAD canister and its contents, would provide for compliance with transportation safety functional requirements including containment, radiological protection, criticality safety, and thermal performance during normal conditions of transport (NCT) and hypothetical accident conditions (HAC).

\subsubsection{Transportation Skid}

The transportation skid (or cradle) would be the means of handling assembled transportation packages at various sites and during intermodal transfers. The transportation skid is the interface between the shipping cask (consisting of one or more STAD canisters in a transportation overpack) and the railcar.

\subsubsection{Ancillary Equipment}

Ancillary equipment is any general or site-specific equipment that would be required to operate and handle STAD system components in accordance with their CoCs and other regulatory or operational requirements. Ancillary equipment to be used at the repository would be developed in the future. Any ancillary equipment needed for use at reactor sites is expected to be similar to commercially available equipment in common usage.

\subsubsection{Disposal Overpack}

The disposal overpack, in which the STAD canister(s) would be sealed prior to final emplacement in the repository subsurface, is outside the scope of this performance specification document. 


\subsection{Approach}

The STAD canister would be designed to perform in three applications-storage, transportation, and disposal — each of which is regulated separately. In each application, the STAD canister would perform as part of an integrated system. The regulatory requirements address the integrated system rather than addressing the STAD canister as a separate entity. This performance specification document clarifies the regulatory requirements for the STAD canister and for the STAD canister inside a storage or transportation overpack. Some STAD canister performance specifications are informed by disposal considerations that are anticipated for future repository licensing.

Storage is regulated by 10 CFR Part 72, Licensing Requirements for the Independent Storage of Spent Nuclear Fuel, High-Level Radioactive Waste, and Reactor-Related Greater than Class C Waste. The US Nuclear Regulatory Commission (NRC) has developed review plans for license applications. The review plan for storage cask systems is NUREG-1536 Revision 1, Standard Review Plan for Dry Cask Storage Systems at a General License Facility. The review plan for storage facilities (e.g., an ISF) is NUREG1567, Standard Review Plan for Spent Fuel Dry Storage Facilities. The NRC has also developed regulatory guides to assist applicants; the most important for storage is Regulatory Guide 3.61, Standard Format and Content for a Topical Safety Analysis Report for a Spent Fuel Dry Storage Cask.

The key source of regulatory requirements for transportation of SNF is 10 CFR Part 71, Packaging and Transportation of Radioactive Material. The NRC review plan most relevant to transportation of SNF is NUREG-1617, Standard Review Plan for Transportation Packages for Spent Nuclear Fuel. The most important regulatory guide for transportation of SNF is Regulatory Guide 7.9 Revision 2, Standard Format and Content of Part 71 Applications for Approval of Packages for Radioactive Material.

Standard review plans (NUREGs) provide regulatory compliance approaches previously endorsed by the NRC staff. Using these approaches in a CoC application or in a license application for a new ISFSI or ISF will streamline the review process compared to the effort and time NRC staff would need to use to review new approaches. Therefore, this performance specification document is based on treating these approaches from the NUREGs (and associated regulatory guides and interim staff guidance documents) as if they were requirements (rather than guidance) unless the STAD system itself is incompatible with those approaches and a new approach is needed.

In the context of this performance specification document, the term "approved contents" is defined as the loaded STAD canister(s) in either of the following:

a) storage overpack: The materials to be stored are defined in NRC Regulatory Guide 3.61 and listed in Section 6, Approved Contents, of CoCs issued under 10 CFR Part 72.

b) transportation overpack: The contents of Type B packaging are defined in NRC Regulatory Guide 7.9 Rev. 2 and listed in Section 5b, Contents of Packaging, of CoCs issued under 10 CFR Part 71.

The regulatory documents require using the radiation safety ALARA (as low as [is] reasonably achievable) principle for minimizing radiological impacts. This performance specification document follows the ALARA principles for both public and worker health and safety.

Section 2 of this specification lists references that are the sources of requirements or guidance, with abbreviated citations. Section 5 lists all references for this document, including more complete citations for the references in Section 2. Section 3 lists the performance specifications for each component of the STAD system. A glossary is provided in Section 4. 


\subsection{Limitations}

Some elements of this STAD specification are derived based on performance considerations for potential geologic disposal. The regulatory basis for this STAD specification is limited to storage and transportation and does not include repository operations and disposal.

\subsection{Quality Assurance}

This performance specification document was prepared under the ORNL QA Program, which is based on ASME-NQA-1-2008 with the NQA-1a-2009 Addenda. The NRC has endorsed versions of ASME NQA-1 as meeting many of the regulatory requirements for QA programs. In RG 7.10 Rev 2 (Transportation QA, issued in 2005), the NRC endorsed ASME-NQA-1-1983 in its entirety as meeting the requirements of 10 CFR Part 71 Subpart H. In RG 1.28 Rev 4 (NPP QA, issued in 2010), the NRC endorsed use of ASMENQA-1-2008 including the NQA-1a-2009 Addenda, subject to a set of additions and modifications listed in the RG. The NRC has as yet made no endorsement of the 2012 or 2015 versions of NQA-1. 
Performance Specification for Standardized Transportation, Aging, and Disposal Canister Systems, FCRD-NFST-2014-000579, Rev. 2 July 20, 2015

\section{PAGE INTENTIONALLY LEFT BLANK}




\section{REQUIREMENTS AND GUIDANCE DOCUMENTS, CODES AND STANDARDS}

This section lists references providing requirements or guidance for storage and transportation systems that may include the STAD canister as a subsystem. The reference citations in this section are abbreviated but are adequate for document identification. Complete citations for these and other references are listed in Section 5.

The list of applicable guidance documents, codes, and standards is not comprehensive. Additional guidance documents, codes, and standards may be identified as applicable based on the specific design of the STAD canister system.

The references cited in this section also cite other references that may be needed to comply with this performance specification document. Some but not all of those references are cited in Section 5 .

The most recent versions of all references are cited in this document (as of early 2015); however, it is recognized that some $\mathrm{CoC}$ and license applicants will use earlier versions of some references in accordance with their existing NRC-accepted quality assurance programs.

\subsection{Regulations}

10 CFR Part 20, "Standards for Protection against Radiation."

10 CFR Part 71, "Packaging and Transportation of Radioactive Material."

10 CFR Part 72, "Licensing Requirements for the Independent Storage of Spent Nuclear Fuel, High-Level Radioactive Waste, and Reactor-Related Greater than Class C Waste."

10 CFR Part 73, "Physical Protection of Plants and Materials."

\subsection{DOE Documents}

Feldman M., S. J. Maheras, and R. E. Best. 2014. AAR S-2043 Cask Railcar System Requirements Document. FCRD-NFST-2014-000093.

\subsection{NRC Documents}

The following is a list of NRC review plans relevant to STAD canister systems for storage and transportation. A more comprehensive list of NUREGs is provided in Section 5.

NUREG-1536, Revision 1, Standard Review Plan for Dry Cask Storage Systems at a General License Facility.

NUREG-1567, Standard Review Plan for Spent Fuel Dry Storage Facilities.

NUREG-1617, Standard Review Plan for Transportation Packages for Spent Nuclear Fuel.

The following is a list of NRC regulatory guides relevant to STAD canister systems for storage and transportation. A more comprehensive list of RGs is provided in Section 5.

Regulatory Guide 3.61, Standard Format and Content for a Topical Safety Analysis Report for a Spent Fuel Dry Storage Cask. 
Regulatory Guide 7.9, Revision 2, Standard Format and Content of Part 71 Applications for Approval of Packages for Radioactive Material.

| The following is a list of NRC guidance documents relevant to STAD canister systems for storage and transportation. A more comprehensive list of ISGs is provided in Section 5.

Spent Fuel Storage and Transportation (SFST)-ISG-8, Revision 3, Burnup Credit in the Criticality Safety Analyses of PWR Spent Fuel in Transport and Storage Casks.

SFST-ISG-11, Revision 3, Cladding Considerations for the Transportation and Storage of Spent Fuel.

SFST-ISG-19, Moderator Exclusion under Hypothetical Accident Conditions and Demonstrating Subcriticality of Spent Fuel under the Requirements of 10 CFR 71.55(e).

The following NRC NUREG and interim staff guidance documents pertaining to the NRC's review of a repository license application (DOE, 2008a) could be relevant to ISFs or aging and handling facilities at a geologic disposal site that may be under a risk-informed performance-based regulation as opposed to the current code-based deterministic regulations for storage and transportation.

NUREG-1804, Revision 2, Yucca Mountain Review Plan.

HLWRS-ISG-01, Review Methodology for Seismically Initiated Event Sequences.

\subsection{Codes and Standards}

AAR (Association of American Railroads) Manual of Standards and Recommended Practices, Section C: Car Construction Fundamentals and Details, Standard S-2043: Performance Specification For Trains Used To Carry High-Level Radioactive Material. Feldman et al. (2014) discusses this standard.

American National Standards Institute (ANSI) N14.5-2014. Radioactive Materials - Leakage Tests on Packages for Shipment.

ASME Boiler and Pressure Vessel Code. 2013 Edition.

American Society for Testing and Materials (ASTM) A-276-13a. Standard Specification for Stainless Steel Bars and Shapes.

ASTM A887-89 (2014). Standard Specification for Borated Stainless Steel Plate, Sheet, and Strip for Nuclear Application. 


\section{PERFORMANCE REQUIREMENTS}

The design criteria and performance specifications for the following STAD canister system components are provided in this section; other components (e.g., disposal overpack) are outside the scope of this document.

- Standardized transportation, aging, and disposal canister

- Storage and aging configurations

- Transportation overpack

- Shielded transfer cask

- Site transporter

- Transportation skid

An overview of the upper-level requirements documents is provided in Section 1.3 of this performance specification document. This section applies those upper-level requirements to the STAD canister system components.

This performance specification document has been developed in a manner intended to facilitate issuance of CoCs for STAD canister system components. The approved approaches (guidance) provided in NRC documents are used as requirements to fulfill this objective. The current specification is limited to undamaged SNF assemblies, which comprise the majority of the SNF inventory. The ability to accommodate damaged fuel cans, consolidated fuel rods, and fuel debris will be a consideration in a future revision of the STAD performance specification document.

\subsection{STAD Canister}

This section provides the performance requirements of the STAD canister, which could be part of NRCcertified systems that are approved for storage, transportation, aging, and disposal. The STAD canister includes a canister shell, lid(s), and components (e.g., basket for holding fuel assemblies, thermal shunts, neutron absorbers) needed to perform its safety functions. The performance specifications for the STAD canister, in conjunction with the STAD canister-based system components, as applicable, are provided in the following subsections.

\subsubsection{General}

1. The 10 CFR Part 71 and 10 CFR Part 72 requirements apply to the loaded STAD canister in a transportation or storage overpack, respectively. NUREG-1536 Rev. 1 and NUREG-1567 for storage, and NUREG-1617 for transportation, provide approaches that have been accepted by the NRC staff in the past. Although these approaches are considered as guidance by the NRC, they are used as requirements in this performance specification document. Applicants may use alternative approaches if the previously accepted approaches are not applicable to the particular circumstances of the STAD canister.

2. The design lifetime of the STAD canister shall be 150 years from the time the canister is loaded with SNF to the time the canister is loaded into a disposal overpack; that period could include multiple dry storage and transportation cycles. It is acceptable to use aging management protocols and/or engineered measures to ensure continued compliance with applicable requirements.

3. The capacity of the small STAD canister shall be either four PWR SNF assemblies or nine BWR SNF assemblies. The outside diameters of the small PWR and BWR canisters shall be the same.

4. The capacity of the medium STAD canister shall be either 12 PWR SNF assemblies or 32 BWR SNF assemblies. The outside diameters of the medium PWR and BWR canisters shall be the same. 
5. The capacity of the large STAD canister shall be either 21 PWR SNF assemblies or 44 BWR SNF assemblies. The outside diameters of the large PWR and BWR canisters shall be the same.

6. A STAD canister shall be capable of being loaded with SNF from all facilities licensed by the NRC and holding a contract with DOE for disposal of SNF.

7. A STAD canister shall be capable of accepting undamaged PWR or BWR SNF assemblies with initial enrichment up to $5 \mathrm{wt} \%{ }^{235} \mathrm{U}$ and burnup up to 62.5 gigawatt day $(\mathrm{GWd}) /$ metric tons of uranium (MTU). Required cooling (decay) time before loading shall be at least one year and depends on enrichment, burnup, and assembly design.

8. The STAD canister shall be designed for storage in either a horizontal or vertical orientation.

9. A STAD canister shall be designed for transportation between sites in a horizontal configuration.

10. The STAD canister is required to have a circular cross section (in the plane perpendicular to the canister's long axis).

11. The STAD canister design shall accommodate the varying lengths of the current inventory of SNF (including non-fuel components [e.g., rod cluster control assemblies]) by using a flexible design that can be fabricated at more than one length. The design shall be integrated with storage overpack and transportation overpack designs and with dimensional clearances at existing reactor facilities.

12. The loaded and closed STAD canister shall be capable of being cut open while submerged in a borated or nonborated pool.

13. Loading operations for each STAD canister capacity variant shall be compatible with load limits and crane-lifting capacities at all existing reactor sites with a handling capacity of at least 100 tons. Design of multiple STC variants to accommodate a range of crane capacities is acceptable.

14. The canister-lifting feature shall be incorporated into the canister top lid and shall not protrude beyond the canister sidewalls.

15. All external edges of the STAD canister shall have a radius of curvature sufficient to protect against gouging of the internal surfaces of the overpacks.

16. Projections or protuberances from reasonably smooth, adjacent surfaces shall be avoided or smoothly blended into the adjacent smooth surfaces so that loading into a storage or transportation overpack will be facilitated with a low potential for damage to the interior of the overpack.

\subsubsection{Structural}

1. There are no structural requirements or elaborations on requirements beyond those necessary to meet 10 CFR Parts 71 and 72, including applicable acceptance criteria in associated review plans (NUREG1536 Rev. 1, NUREG-1567, and NUREG-1617) with applicable NRC ISG documents.

\subsubsection{Thermal}

1. SNF cladding temperatures in STAD canisters shall meet applicable limits established in NUREG-1536 Rev. 1 for storage and loading operations. For transportation, the cladding temperatures in STAD canisters during NCT shall not exceed $400^{\circ} \mathrm{C}$. For transportation HAC, this specification does not impose cladding temperature limits.

2. To meet repository thermal management objectives, the maximum cladding temperature after disposal shall not exceed $400^{\circ} \mathrm{C}$ given emplacement of a disposal overpack containing a single STAD canister with the power and surface temperature boundary conditions provided in Table 1. For the purpose of 
canister internal temperature analysis, the canister outer surface temperature may be assumed to be $2^{\circ} \mathrm{C}$ hotter than the disposal overpack outer surface temperature.

Table 1. Thermal boundary conditions for disposal

\begin{tabular}{|l|c|c|}
\hline \multicolumn{1}{|c|}{ Concept } & $\begin{array}{c}\text { STAD canister } \\
\text { thermal power }\end{array}$ & $\begin{array}{c}\text { Disposal overpack surface } \\
\text { temperature boundary condition }\end{array}$ \\
\hline Small STAD canister & $2,200 \mathrm{~W}$ & $200^{\circ} \mathrm{C}$ \\
\hline Medium STAD canister & $5,500 \mathrm{~W}$ & $200^{\circ} \mathrm{C}$ \\
\hline Large STAD canister & $10,000 \mathrm{~W}$ & $200^{\circ} \mathrm{C}$ \\
\hline
\end{tabular}

\subsubsection{Radiation Protection and Shielding}

1. Other than listed below, there are no radiation protection or shielding requirements or elaborations on requirements beyond those necessary to meet 10 CFR Parts 20,71, and 72, including applicable acceptance criteria in associated review plans (NUREG-1536 Rev. 1, NUREG-1567, and NUREG1617) with applicable NRC ISG documents.

2. The STAD canister shall be designed so that removable surface contamination on an accessible external surface shall be less than $1,000 \mathrm{dpm} / 100 \mathrm{~cm}^{2}$ beta-gamma and $20 \mathrm{dpm} / 100 \mathrm{~cm}^{2}$ alpha.

\subsubsection{Criticality}

1. Other than listed below, there are no criticality safety requirements or elaborations on requirements beyond those necessary to meet 10 CFR Parts 71 and 72, including applicable acceptance criteria in associated review plans (NUREG-1536 Rev. 1, NUREG-1567, and NUREG-1617) with applicable NRC ISG documents.

2. SFST-ISG-8 Rev. 3, Burnup Credit in the Criticality Safety Analyses of PWR Spent Fuel in Transport and Storage Casks, shall be applied.

3. SFST-ISG-19, Moderator Exclusion under Hypothetical Accident Conditions and Demonstrating Subcriticality of Spent Fuel under the Requirements of 10 CFR 71.55(e), shall be applied to ensure that moderator exclusion under HAC can be used as a design approach and $\mathrm{CoC}$ basis.

4. To meet repository objectives, the following six requirements are prescribed as a group:

a) Neutron absorber plates or tubes shall be made from borated stainless steel produced by powder metallurgy and meeting ASTM A887-89 (2014), Standard Specification for Borated Stainless Steel Plate, Sheet, and Strip for Nuclear Application, Grade A alloys.

b) Minimum thickness of neutron absorber plates between SNF assemblies shall be $11 \mathrm{~mm}(0.4375$ in.), assuming single plates. Use of multiple plates between the SNF assemblies (i.e., flux traps) is prohibited.

c) The neutron absorber plate shall have boron content of 1.1-1.2 wt \%, a range that falls within the specification range for 304B4 (Unified Numbering System [UNS] S30464) as described in ASTM A887-89 (2014).

d) Neutron-absorbing material shall extend the full length of the fuel basket.

e) Neutron-absorbing plates shall either surround each assembly or extend the full cross section of the STAD canister (in the plane perpendicular to the canister's long axis).

f) The borated stainless steel plates shall be incorporated into the basket without the use of welding. 


\subsubsection{Confinement and Containment}

1. Other than listed below, there are no confinement and containment requirements or elaborations on requirements beyond those necessary to meet 10 CFR Parts 71 and 72, including applicable acceptance criteria in associated review plans (NUREG-1536 Rev. 1, NUREG-1567, and NUREG-1617) with applicable NRC ISG documents.

2. The STAD canister shall be designed to be "leak tight" as defined in ANSI N14.5-2014.

3. The STAD canister shall constitute the confinement boundary during storage. 10 CFR Part 72.236 requires redundant sealing of confinement systems for a storage cask. This performance specification document assigns that requirement to the STAD canister, requiring dual welded closures.

4. Helium shall be the STAD canister fill gas for storage and transportation.

5. Because STAD canisters may be stored at sites with a wide range of seismological characteristics, the design of the STAD canister shall assume a standardized design earthquake (DE) ground motion described by an appropriate response spectrum anchored at $3 \mathrm{~g}$ in lieu of the regionally- and geologically-based seismological characteristics described in 10 CFR 72.103. Following a seismic event characterized by horizontal and vertical peak ground accelerations of $3 \mathrm{~g}$, the STAD canister in a storage or aging configuration shall maintain confinement consistent with the requirements of $10 \mathrm{CFR}$ Part 72 and the guidance in NUREG-1536, Rev. 1.

\subsubsection{Operations}

1. Other than listed below, there are no operations requirements or elaborations on requirements beyond those necessary to meet 10 CFR Parts 71 and 72, including applicable acceptance criteria in associated review plans (NUREG-1536 Rev. 1, NUREG-1567, and NUREG-1617) with applicable NRC ISG documents.

2. The STAD canister lid shall be designed for handling under water with the STAD canister in a vertical orientation.

3. A feature for lifting a vertically oriented loaded STAD canister, with the lifting feature mating with the lid, shall be provided. The lifting feature may be integral with the lid or mechanically attached.

4. An open, empty, and vertically oriented STAD canister shall have integral lifting feature(s) provided to allow lifting by an overhead handling system.

5. It is acceptable to use a carrier approach to load, close, and move STAD canisters in groups.

\subsubsection{Materials}

1. Other than listed below, there are no materials requirements or elaborations on requirements beyond those necessary to meet $10 \mathrm{CFR}$ Parts 71 and 72, including applicable acceptance criteria in associated review plans (NUREG-1536 Rev. 1, NUREG-1567, and NUREG-1617) with applicable NRC ISG documents.

2. The STAD canister shell and lid shall be designed and fabricated in accordance with the ASME (2013) Boiler and Pressure Vessel Code, Section III, Division 1, Subsection NB or NC to the extent practicable. The vendor shall identify applicable code exceptions, clarifications, interpretations, and code cases.

3. Required Materials - The STAD canister and structural internals (i.e., basket, but not thermal shunts and criticality control materials) shall be Type 300-series stainless steel as listed in ASTM A-276-13a, Standard Specification for Stainless Steel Bars and Shapes. 
4. Potential problems from uniform corrosion, pitting, stress corrosion cracking, or other types of corrosion shall be evaluated for the environmental conditions and dynamic loading effects that are specific to the component. Because it is assumed that a separately evaluated disposal overpack will be used for disposal, this requirement refers to environmental conditions during storage or aging as well as during transport.

5. All external welds except the closure welds shall be treated (e.g., stress relieved) prior to loading to mitigate the potential for stress corrosion cracking. The final closure welds shall be capable of being treated after loading. The triggers and timing for treating the final closure welds shall be determined as part of the aging management plan developed in support of CoCs and licenses.

6. The STAD canister and its basket materials shall be designed to be compatible with both borated and nonborated pool water.

7. The following is a list of prohibited or restricted materials.

a) The STAD canister shall not use organic, hydrocarbon-based materials of construction.

b) The STAD canister shall not be constructed of pyrophoric materials.

c) The STAD canister (including the basket, thermal shunts, criticality control materials, gaskets, seals, adhesives, and solder) shall not be constructed with materials that would be regulated as hazardous wastes under the Resource Conservation and Recovery Act (RCRA) and prohibited from land disposal under RCRA if declared to be waste. Specific sections of the Environmental Protection Agency (EPA) regulations defining hazardous wastes are listed in Section 4 of this performance specification document (Glossary).

8. The following is a list of marking requirements.

a) The STAD canister shall be capable of being marked on the lid and body with an identical unique (vendor independent) identifier prior to delivery for loading.

b) The markings shall remain legible for the 150-year service life of the STAD canister without intervention or maintenance during normal operations and off-normal conditions associated with loading, closure, storage, transportation, aging, and placement in a disposal overpack.

\subsubsection{Security}

1. There are no security requirements or elaborations on requirements beyond those necessary to meet 10 CFR Parts 71 and 72, including applicable acceptance criteria in associated review plans (NUREG1536 Rev. 1, NUREG-1567, and NUREG-1617) with applicable NRC ISG documents. Note that 10 CFR Parts 71 and 72 invoke compliance with 10 CFR Part 73, "Physical Protection of Plants and Materials."

\subsection{Storage and Aging Configurations}

1. Other than listed below, there are no requirements specific to the storage and aging configuration or elaborations on requirements beyond those necessary to meet 10 CFR Part 72, including applicable acceptance criteria in associated review plans (NUREG-1536 Rev. 1 and NUREG-1567) with applicable NRC ISG documents.

2. Storage and aging configurations for STAD canisters include the use of overpacks, modules, or vault systems.

3. Overpacks/modules may be designed to accommodate single or multiple STAD canisters. The use of a multicanister fixture to facilitate handling and/or storage is acceptable. 
4. Vault systems will provide similar functions to storage/aging overpacks or modules, but they may contain active components for cooling.

5. Storage and aging configurations shall have features that permit periodic monitoring and maintenance of the STAD canister for its 150-year service life. Maintenance or replacement of storage and aging systems during the STAD canister service life is acceptable.

6. Because STAD canisters may be stored at sites with a wide range of seismological characteristics, two storage/aging overpack/module variants shall be designed assuming two standardized design earthquake (DE) ground motions described by appropriate response spectra anchored at $0.75 \mathrm{~g}$ and $0.25 \mathrm{~g}$ in lieu of the regionally- and geologically-based seismological characteristics described in 10 CFR 72.103.

\subsection{Shielded Transfer Cask}

1. There are no requirements specific to the STC or elaborations on requirements beyond those necessary to meet 10 CFR Part 72, including applicable acceptance criteria in associated review plans (NUREG1536 Rev. 1 and NUREG-1567) with applicable NRC ISG documents.

\subsection{Site Transporter}

1. There are no requirements specific to the site transporter or elaborations on requirements beyond those necessary to meet 10 CFR Part 72, including applicable acceptance criteria in associated review plans (NUREG-1536 Rev. 1 and NUREG-1567) with applicable NRC ISG documents.

\subsection{Transportation Overpack}

1. Other than those listed below, there are no requirements specific to the transportation overpack or elaborations on requirements beyond those necessary to meet 10 CFR Part 71, including applicable acceptance criteria in the associated review plan (NUREG-1617) with applicable NRC ISG documents.

2. The transportation overpack cavity may be designed to accommodate single or multiple STAD canisters. The use of a multicanister fixture to facilitate handling and/or transportation is acceptable.

3. The loaded transportation overpack (without impact limiters) shall be capable of being lifted in a vertical orientation by an overhead crane.

4. The loaded transportation overpack (without impact limiters) shall be able to stand upright when set down upon a flat horizontal surface without requiring the use of auxiliary supports.

5. The transportation overpack shall be designed such that removable surface contamination on an accessible external surface shall be less than $1,000 \mathrm{dpm} / 100 \mathrm{~cm}^{2}$ beta-gamma and $20 \mathrm{dpm} / 100 \mathrm{~cm}^{2}$ alpha.

\subsection{Transportation Skid}

The STAD system interfaces with the railcar at the transportation skid. The AAR S-2043 Cask Railcar System Requirements Document (Feldman 2014) summarizes the requirements of the American Association of Railroads Manual of Standards and Recommended Practices.

1. The transportation skid shall be designed to permit the loaded transportation overpack, without impact limiters, to be upended and lifted vertically from the transportation skid via overhead crane.

2. The transportation skid shall facilitate lifting of the loaded transportation overpack (including the impact limiters), in a horizontal orientation, and transfer of the transportation overpack from one 
Performance Specification for Standardized Transportation, Aging, and Disposal Canister Systems, FCRD-NFST-2014-000579, Rev. 2

July 20, 2015

conveyance to another. The attachment of the transportation skid to the railcar shall be in accordance with the requirements of AAR Interchange Rule 88, A.16.c(3) (AAR, 2008).

\subsection{Quality Assurance}

1. Quality assurance program(s) consistent with the requirements of 10 CFR Part 71, Subpart H (packaging and transportation) and 10 CFR Part 72, Subpart G (storage) shall be used for the design, purchase, fabrication, handling, shipping, storing, cleaning, assembly, inspection, testing, operation, maintenance, repair, modifications, and decommissioning of the STAD canister systems. 
Performance Specification for Standardized Transportation, Aging, and Disposal Canister Systems, FCRD-NFST-2014-000579, Rev. 2 July 20, 2015

\section{PAGE INTENTIONALLY LEFT BLANK}




\section{GLOSSARY}

This section provides definitions and descriptions of major terms of art used throughout this document.

Aging - Safely placing commercial SNF in a storage overpack/module/vault on an aging pad to allow the SNF to cool via radioactive decay. Safe aging of SNF is a prerequisite for transportation and/or geologic disposal to ensure that the SNF has sufficiently decayed (cooled) to meet licensed thermal limits for transportation and/or repository emplacement.

Burnup - A measure of nuclear reactor fuel consumption expressed either as the percentage of fuel atoms that have undergone fission or as the amount of energy produced per initial unit weight of fuel.

Canister - A structure enclosing one or more SNF assemblies that facilitates handling, storage, aging, transportation, and disposal.

Design bases - Information that identifies the specific functions to be performed by a structure, system, or component of a facility and the specific values or ranges of values chosen for controlling parameters as reference bounds for design. These values may be constraints derived from generally accepted state-of-theart practices for achieving functional goals or requirements derived from analysis (based on calculation or experiments) of the effects of a postulated event under which a structure, system, or component must meet its functional goals. The values for controlling parameters for external events include:

- estimates of severe natural events to be used for deriving design bases that are based on consideration of physical data, historical data on the associated parameters, or analysis of upper limits of the physical processes involved, and

- estimates of severe external human-induced events to be used for deriving design bases that are based on analysis of human activity in the region, taking into account the site characteristics and the risks associated with the event.

Event sequence (repository) - A series of actions and/or occurrences within the natural and engineered components of a geologic repository that could lead to exposure of individuals to radiation. An event sequence includes one or more initiating events and associated combinations of repository system component failures, including those produced by the action or inaction of operating personnel.

Fuel assembly - A number of fuel rods held together by plates and separated by spacers, to allow coolant to flow over the rods in a reactor. This assembly is sometimes called a fuel bundle or fuel element.

Hazardous wastes (under the Resource Conservation and Recovery Act, RCRA) - According to the EPA website, hazardous waste has properties that make it dangerous or potentially harmful to human health or the environment. In regulatory terms, RCRA hazardous wastes fall into two categories:

- Listed wastes appearing on one of the four EPA hazardous wastes lists:

- $\quad$ The F-list (non-specific source wastes), 40 CFR 261.31.

- $\quad$ The K-list (source-specific wastes), 40 CFR 261.32.

- $\quad$ The P-list and the U-list (discarded commercial chemical products), 40 CFR 261.33.

- Characteristic wastes exhibiting one or more of four characteristics defined in 40 CFR Part 261, Subpart C:

- Ignitability, 40 CFR 261.21.

- Corrosivity, 40 CFR 261.22.

- Reactivity, 40 CFR 261.23.

- $\quad$ Toxicity, 40 CFR 261.24. 
High-level radioactive waste (HLW) - (1) The highly radioactive material resulting from reprocessing of SNF, including liquid waste produced directly in reprocessing and any solid material derived from such liquid waste that contains fission products in sufficient concentrations; and (2) other highly radioactive material that the NRC, consistent with existing law, determines by rule requires permanent isolation.

Hypothetical accident conditions (HAC) - The sequential conditions and tests defined in 10 CFR Part 71, Subpart E, "Package Approval Standards," and Subpart F, "Package, Special Form and LSA-III Tests," against which a package or array of packages must be evaluated.

Important to safety - The phrase "structures, systems, and components important to safety" refers to those features of the ISFSI, ISF, loaded SNF storage overpack, loaded SNF transportation cask, and repository waste package, whose functions are to

- maintain the conditions required to store, transport, and dispose of SNF or reactor-related greater than class C (GTCC) low-level radioactive waste safely,

- prevent damage to the SNF or reactor-related GTCC waste container during handling, storage, transportation, and disposal, and

- provide reasonable assurance that SNF or reactor-related GTCC waste can be received, handled, packaged, stored, retrieved, transported, and disposed without undue risk to the health and safety of the public.

Neutron absorber - A material (e.g., boron) that absorbs neutrons and is used for criticality control.

Normal conditions of transport (NCT) - The conditions and tests defined in 10 CFR Part 71, Subpart E, "Package Approval Standards," and Subpart F, "Package, Special Form and LSA-III Tests," that all packages must be evaluated against during normal situations.

Overpack - The outer container component for storage, transportation, or disposal. The overpack can contain a single STAD canister or multiple STAD canisters in a carrier or basket.

Shielded transfer cask (STC) - A cask that meets applicable 10 CFR Part 72 requirements for safe transfer of a STAD canister and its contents within various surface facilities.

Site transporter - A system to transport loaded or empty STCs within a storage site (ISFSI or ISF), licensed in accordance with 10 CFR Part 72. The site transporter may also be capable of moving the loaded transportation overpack (with or without the transportation skid). Alternatively, the applicant may design separate transporters for the STC and transportation overpack.

Spent nuclear fuel (SNF) - Fuel that has been withdrawn from a nuclear reactor following irradiation, the constituent elements of which have not been separated by reprocessing. 10 CFR 71.4 and 72.2 further define "spent nuclear fuel" as fuel that has been discharged from the reactor for at least one year.

Storage - For the purposes of this specification, the placement of SNF in an ISFSI licensed in accordance with 10 CFR Part 72.

Standard transportation, aging, and disposal (STAD) system - the set of components consisting of one or more STAD canisters, storage/aging overpacks/modules/vaults, shielded transfer casks, site transporters, transportation overpacks, transportation skids, and ancillary equipment used to facilitate handling of SNF.

Undamaged SNF - SNF that can meet all fuel-specific and system-related functions. Undamaged fuel may be breached and may have assembly defects (per SFST-ISG-1, Revision 2).

Waste package - The waste form and any containers (disposal overpack), shielding, packing, and other materials immediately surrounding an individual waste container. 


\section{REFERENCES}

The citation sequences in this section are alphabetical by author except where the reference designator is a more logical locator (e.g., CFR, NUREG, and regulatory guide references). Many of these references are not cited in this document but are cited within references that this document cites. Some reference citations are annotated to indicate their status or usage.

10 CFR Part 20, "Standards for Protection against Radiation." Washington, DC: US Government Publishing Office.

10 CFR Part 21, "Reporting of Defects and Noncompliance.” Washington, DC: US Government Publishing Office.

10 CFR Part 50, "Domestic Licensing of Production and Utilization Facilities.” Washington, DC: US Government Publishing Office.

10 CFR Part 71, "Packaging and Transportation of Radioactive Material." Washington, DC: US Government Publishing Office.

10 CFR Part 72, "Licensing Requirements for the Independent Storage of Spent Nuclear Fuel, High-Level Radioactive Waste, and Reactor-Related Greater than Class C Waste." Washington, DC: US Government Publishing Office.

10 CFR Part 73, "Physical Protection of Plants and Materials." Washington, DC: US Government Publishing Office.

40 CFR Part 261, "Identification and Listing of Hazardous Waste." Washington, DC: US Government Publishing Office.

49 CFR Part 173, "Shippers - General Requirements for Shipments and Packagings.” Washington, DC: US Government Publishing Office.

AAR. 2008. Manual of Standards and Recommended Practices, Section C: "Car Construction Fundamentals and Details," Standard S-2043: Performance Specification for Trains Used to Carry HighLevel Radioactive Material. Washington, DC: Association of American Railroads. [Feldman (2014) summarizes pertinent requirements from this reference.]

American Association of State Highway and Transportation Officials (AASHTO). 2011. A Policy on Geometric Design of Highways and Streets. $6^{\text {th }}$ Edition. Washington, DC: American Association of State Highway and Transportation Officials.

ANSI/American Nuclear Society (ANS) 57.9-1992-R2000-W2010. 1992. Design Criteria for an Independent Spent Fuel Storage Installation (Dry Type). La Grange Park, IL: ANS (1992). [This standard was reaffirmed in 2000 and withdrawn in 2010. It is available from ANS but not from ANSI.]

ANSI N14.5-2014. 2014. Radioactive Materials - Leakage Tests on Packages for Shipment. New York, NY: American National Standards Institute.

ANSI N14.6-1993. 1993. Special Lifting Devices for Shipping Containers Weighing 10,000 Pounds (4500 kg) or More. New York, NY: American National Standards Institute. [This standard has been withdrawn by ANSI, but is cited by NUREG-0612 and DOE-STD-1090-2007, as well as by many industry 
licensing analyses, publications, and websites. It is retained here because some current licensees that may consider use of the STAD system are currently using ANSI N14.6 for reactor site storage. The most current DOE-STD-1090-2011 no longer cites ANSI N14.6, but continues to cite ASME B30.20, 2013 being the most current version

| ASME NQA-1-2015. 2015. Quality Assurance Requirements for Nuclear Facility Applications. New York, NY: American Society of Mechanical Engineers.

ASME B30.20. 2013. Below-the-Hook Lifting Devices. New York, NY: American Society of Mechanical Engineers.

ASME Boiler and Pressure Vessel Code. 2013 Edition. New York, NY: American Society of Mechanical Engineers.

ASTM A-276-13a (2013). Standard Specification for Stainless Steel Bars and Shapes. West Conshohocken, PA: ASTM International.

ASTM A887-89 (2014). Standard Specification for Borated Stainless Steel Plate, Sheet, and Strip for Nuclear Application. West Conshohocken, PA: ASTM International.

ASTM B932-04 (2010). Standard Specification for Low-Carbon Nickel-Chromium-MolybdenumGadolinium Alloy Plate, Sheet and Strip. West Conshohocken, PA: ASTM International.

ASTM SI10-10, Institute of Electrical and Electronics Engineers (IEEE)/ASTM SI 10. 2010. American National Standard for Metric Practice. West Conshohocken, PA: ASTM International.

DOE 2008a. Yucca Mountain Repository License Application, Safety Analysis Report. DOE/RW-0573, Revision 0. Washington, DC: US DOE (2008).

DOE 2008b. Transportation, Aging and Disposal Canister System Performance Specification Requirements Rationale. WMO-TADCS-RR-000001, Revision 1, ICN 1. Washington, DC: US DOE (2008).

DOE 2008c. Transportation, Aging and Disposal Canister System Performance Specification. WMOTADCS-000001, Revision 1, ICN 1. Washington, DC: US DOE (2008).

DOE 2011. Hoisting and Rigging (formerly Hoisting and Rigging Manual). DOE-STD-1090-2011. Washington, DC: US DOE (2011).

Feldman M., S. J. Maheras, and R. E. Best. 2014. AAR S-2043 Cask Railcar System Requirements Document. Report No. FCRD-NFST-2014-000093. Washington, DC: US DOE.

Hardin, E., T. Hadgu, D. Clayton, R. Howard, H. Greenberg, J. Blink, M. Sharma, M. Sutton, J. Carter, M. Dupont and P. Rodwell. 2012. Repository Reference Disposal Concepts and Thermal Load Management Analysis. FCRD-UFD-2012-000219, Rev.2. Washington, DC: US DOE.

Hardin, E., D. Clayton, M. Martinez, G. Neider-Westermann, R. Howard, H. Greenberg, J. Blink, and T. Buscheck. 2013. Collaborative Report on Disposal Concepts. FCRD-UFD-2013-000170 Rev. 0.

Washington, DC: US DOE. 
International Organization for Standardization (ISO) 1161:1984 $4^{\text {th }}$ Edition. 1984. Series 1 Freight Containers - Corner Fittings - Specification. Geneva, Switzerland: International Organization for Standardization.

ISO 1161:1984/Cor 1: 1990. Series 1 Freight Containers - Corner Fittings - Specification (this Technical Corrigendum 1 corrects an error in a figure). Geneva, Switzerland: International Organization for Standardization.

ISO 1161:1984/Amd 1:2007. Series 1 Freight Containers - Corner Fittings - Specification (Amendment 1 extends scope to 45 foot containers). Geneva, Switzerland: International Organization for Standardization.

NRC 2005. NRC Regulatory Issue Summary 2005-25: Clarification of NRC Guidelines for Control of Heavy Loads. RIS 2005-25. Washington, DC: Nuclear Regulatory Commission. This document was developed by the NRC to address recommendations identified through the investigation of Generic Issue (GI) 186, Potential Risk and Consequences of Heavy Load Drops in Nuclear Power Plants.

NRC 2007. NRC Regulatory Issue Summary 2005-25, Supplement 1: Clarification of NRC Guidelines for Control of Heavy Loads. RIS 2005-25, Supplement 1. Washington, DC: Nuclear Regulatory Commission. This supplement extends the discussion to applicable sections of NUREG-0800, Standard Review Plan for the Review of Safety Analysis Reports for Nuclear Power Plants: LWR Edition.

NRC ISG. 2006. HLWRS-ISG-01. Review Methodology for Seismically Initiated Event Sequences. Washington, DC: Nuclear Regulatory Commission.

NRC ISG ${ }^{\text {a }}$ 2007. SFST-ISG-1, Revision 2. Classifying the Condition of Spent Nuclear Fuel for Interim Storage and Transportation Based on Function [Short title: Damaged Fuel]. Washington, DC: Nuclear Regulatory Commission.

NRC ISG. 2010. SFST-ISG-2, Rev. 1. Fuel Retrievability. Washington, DC: Nuclear Regulatory Commission.

NRC ISG. 1998. SFST-ISG-3. Post Accident Recovery and Compliance with 10 CFR 72.122(l). Washington, DC: Nuclear Regulatory Commission.

NRC ISG. 1998. SFST-ISG-5, Rev. 1. Confinement Evaluation. Washington, DC: Nuclear Regulatory Commission.

NRC ISG. 1998. SFST-ISG-6. Establishing Minimum Initial Enrichment for the Bounding Design Basis Fuel Assembly(s). Washington, DC: Nuclear Regulatory Commission.

NRC ISG. 1998. SFST-ISG-7. Potential Generic Issue Concerning Cask Heat Transfer in a Transportation Accident. Washington, DC: Nuclear Regulatory Commission.

\footnotetext{
${ }^{\text {a }}$ All current SFST-ISGs are listed, along with one current HLWRS-ISG that is pertinent to storage. There are two cancelled SFSTISGs listed on the NRC website (but not available to download): SFST-ISG-24, Draft-Review of Foreign-Approved Transportation Packages, and SFST-ISG-26A, Draft - Shielding and Radiation Protection Review Effort and Licensing Parameters for 10 CFR Part 72 Applications. In addition, NUREG-1536, Rev. 1, states that SFST-ISG-4 Rev. 1, Cask Closure Weld Inspections, has been superseded by SFST-ISG-15, Materials Evaluation, and SFST-ISG-18 Rev. 1, The Design and Testing of Lid Welds on Austenitic Stainless Steel Canisters as the Confinement Boundary for Spent Fuel Storage.
} 
NRC ISG. 2012. SFST-ISG-8, Rev. 3. Burnup Credit in the Criticality Safety Analyses of PWR Spent Fuel in Transport and Storage Casks. Washington, DC: Nuclear Regulatory Commission.

NRC ISG. 2002. SFST-ISG-9, Rev. 1. Storage of Components Associated with Fuel Assemblies. Washington, DC: Nuclear Regulatory Commission.

NRC ISG. 2000. SFST-ISG-10, Rev. 1. Alternatives to the ASME Code. Washington, DC: Nuclear Regulatory Commission.

NRC ISG. 2003. SFST-ISG-11, Rev. 3. Cladding Considerations for the Transportation and Storage of Spent Fuel. Washington, DC: Nuclear Regulatory Commission.

NRC ISG. 1999. SFST-ISG-12, Rev. 1. Buckling of Irradiated Fuel under Bottom End Drop Conditions. Washington, DC: Nuclear Regulatory Commission.

NRC ISG. 2000. SFST-ISG-13. Real Individual. Washington, DC: Nuclear Regulatory Commission.

NRC ISG. 2000. SFST-ISG-14. Supplemental Shielding. Washington, DC: Nuclear Regulatory Commission.

NRC ISG. 2001. SFST-ISG-15. Materials Evaluation. Washington, DC: Nuclear Regulatory Commission.

NRC ISG. 2000. SFST-ISG-16. Emergency Planning. Washington, DC: Nuclear Regulatory Commission.

NRC ISG. 2001. SFST-ISG-17. Interim Storage of Greater Than Class C Waste. Washington, DC:

Nuclear Regulatory Commission.

NRC ISG. 2008. SFST-ISG-18, Rev. 1. The Design and Testing of Lid Welds on Austenitic Stainless Steel Canisters as the Confinement Boundary for Spent Fuel Storage. Washington, DC: Nuclear Regulatory Commission.

NRC ISG. 2003. SFST-ISG-19. Moderator Exclusion under Hypothetical Accident Conditions and Demonstrating Subcriticality of Spent Fuel under the Requirements of 10 CFR 71.55(e). Washington, DC: Nuclear Regulatory Commission.

NRC ISG. 2005. SFST-ISG-20. Transportation Package Design Changes Authorized under 10 CFR Part 71 without Prior NRC Approval. Washington, DC: Nuclear Regulatory Commission.

NRC ISG. 2006. SFST-ISG-21. Use of Computational Modeling Software. Washington, DC: Nuclear Regulatory Commission.

NRC 2006. ISG. SFST-ISG-22. Potential Rod Splitting due to Exposure to an Oxidizing Atmosphere during Short-Term Cask Loading Operations in LWR or other Uranium Oxide Based Fuel. Washington, DC: Nuclear Regulatory Commission.

NRC ISG. 2011. SFST-ISG-23. Application of ASTM Standard Practice C1671-07 when Performing Technical Reviews of Spent Fuel Storage and Transportation Packaging Licensing Actions. Washington, DC: Nuclear Regulatory Commission.

NRC ISG. 2010. SFST-ISG-25. Pressure and Helium Leakage Testing of the Confinement Boundary of Spent Fuel Dry Storage Systems. Washington, DC: Nuclear Regulatory Commission. 
NUREG-0612. 1980. Control of Heavy Loads at Nuclear Power Plants: Resolution of Generic Technical Activity A-36. Washington, DC: Nuclear Regulatory Commission.

NUREG-0800. 2007. Standard Review Plan for the Review of Safety Analysis Reports for Nuclear Power Plants: LWR Edition. Washington, DC: Nuclear Regulatory Commission. Editions for other reactor types are issued under the same number (e.g., 2014 for the Small Modular Reactor Edition).

NUREG-1536, Rev. 1. 2010. Standard Review Plan for Dry Cask Storage Systems at a General License Facility, including applicable ISG documents. Washington, DC: Nuclear Regulatory Commission. [Rev. 1 incorporates SFST-ISG-1 through -26, as applicable. See Appendix C of the NUREG for a list of ISGs incorporated into NUREG-1536 Rev. 1 directly or by reference.]

NUREG-1567. 2000. Standard Review Plan for Spent Fuel Dry Storage Facilities. Washington, DC: Nuclear Regulatory Commission.

NUREG-1609. 1999. Standard Review Plan for Transportation Packages for Radioactive Material. Washington, DC: Nuclear Regulatory Commission.

NUREG-1609, Supplement 2. 2006. Standard Review Plan for Transportation Packages for Irradiated Tritium - Producing Burnable Absorber Rods (TPBARs). Washington, DC: Nuclear Regulatory Commission.

NUREG-1617. 2000. Standard Review Plan for Transportation Packages for Spent Nuclear Fuel. Washington, DC: Nuclear Regulatory Commission.

NUREG-1619. 1998. Standard Review Plan for Physical Protection Plans for the Independent Storage of Spent Fuel and High-Level Radioactive Waste. Washington, DC: Nuclear Regulatory Commission.

NUREG-1804, Rev. 2. 2003. Yucca Mountain Review Plan. Washington, DC: Nuclear Regulatory Commission.

NUREG-1927. 2011. Standard Review Plan for Renewal of Spent Fuel Dry Cask Storage System Licenses and Certificates of Compliance. Washington, DC: Nuclear Regulatory Commission.

NUREG/CR-4461, Rev. 2. 2007. Tornado Climatology of the Contiguous United States. Washington, DC: Nuclear Regulatory Commission.

NUREG/CR-6314. 1996. Quality Assurance Inspections for Shipping and Storage Containers. Washington, DC: Nuclear Regulatory Commission.

NUREG/CR-6407. 1996. Classification of Transportation Packaging and Dry Spent Fuel Storage System Components According to Importance to Safety. Washington, DC: Nuclear Regulatory Commission.

NUREG/CR-6487. 1996. Containment Analysis for Type B Packages Used to Transport Various Contents. Washington, DC: Nuclear Regulatory Commission.

NUREG/CR-6802. 2003. Recommendations for Shielding Evaluations for Transport \& Storage Packages. Washington, DC: Nuclear Regulatory Commission. 
NUREG/CR-6835. 2003. Effects of Fuel Failure on Criticality Safety and Radiation Dose for Spent Fuel Casks. Washington, DC: Nuclear Regulatory Commission.

Regulatory Guide 1.76, Rev. 1. 2007. Design Basis Tornado and Tornado Missiles for Nuclear Power Plants. Washington, DC: Nuclear Regulatory Commission.

Regulatory Guide 3.54, Rev. 1. 1999. Spent Fuel Heat Generation in an Independent Spent Fuel Storage Installation. Washington, DC: Nuclear Regulatory Commission.

Regulatory Guide 3.61. 1989. Standard Format and Content for a Topical Safety Analysis Report for a Spent Fuel Dry Storage Cask. Washington, DC: Nuclear Regulatory Commission.

Regulatory Guide 3.73. 2003. Site Evaluations and Design Earthquake Ground Motion for Dry Cask Independent Spent Fuel Storage and Monitored Retrievable Storage Installations. Washington, DC: Nuclear Regulatory Commission.

Regulatory Guide 7.6, Rev. 1. 1978. Design Criteria for the Structural Analysis of Shipping Cask Containment Vessels. Washington, DC: Nuclear Regulatory Commission.

Regulatory Guide 7.9, Rev. 2. 2005. Standard Format and Content of Part 71 Applications for Approval of Packages for Radioactive Material. Washington, DC: Nuclear Regulatory Commission.

Regulatory Guide 7.10. Rev. 2. 2005. Establishing Quality Assurance Programs for Packaging Used in Transport of Radioactive Material. Washington, DC: Nuclear Regulatory Commission.

Regulatory Guide 7.11. 1991. Fracture Toughness Criteria of Base Material for Ferritic Steel Shipping Cask Containment Vessels with a Maximum Wall Thickness of 4 Inches $(0.1 \mathrm{~m})$. Washington, DC: Nuclear Regulatory Commission.

Regulatory Guide 7.12. 1991. Fracture Toughness Criteria of Base Material for Ferritic Steel Shipping Cask Containment Vessels with a Wall Thickness Greater than 4 Inches $(0.1 \mathrm{~m})$ But Not Exceeding 12 Inches $(0.3 \mathrm{~m})$. Washington, DC: Nuclear Regulatory Commission.

SKB. 2011. Long-Term Safety for the Final Repository for Spent Nuclear Fuel at Forsmark: Main Report of the SR-Site Project. Technical Report TR-11-01, Volumes I, II, and III. Swedish Nuclear Fuel and Waste Management Co. 